\title{
Kidney Disease and Cognitive Function
}

\author{
Merrill F. Elias ${ }^{\mathrm{a}} \cdot$ Gregory A. Dore $^{\mathrm{b}} \cdot$ Adam Davey $^{\mathrm{c}}$

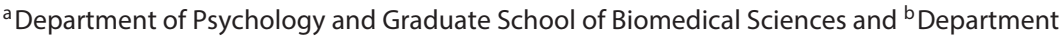 \\ of Psychology, The University of Maine, Orono, Me., and ' Department of Public Health, \\ Temple University, Philadelphia, Pa., USA
}

\begin{abstract}
We provide a brief review of research on chronic kidney disease and cognitive performance, including dementia. We touch briefly on the literature relating end-stage-renal disease to cognitive function, but focus on studies of modest and moderate forms of chronic kidney disease (CKD) that precede dialysis and transplantation. We summarize previous reviews dealing with case control studies of patients but more fully examine community-based studies with large samples and necessary controls for demographic risk factors, cardiovascular variables, and other confounds such as depression. In addition we suggest potential biological and social-psychological mediators between CKD and cognition. Studies follow in two categories of design: (1) cross-sectional studies, and (2) longitudinal studies. In each, CKD is related to a wide range of deficits in cognitive functioning including verbal and visual memory and organization, and components of executive functioning and fluid intellect. In general, prior to the need to treat with hemodialysis (HD) or kidney transplant (KT), magnitude of effect with relation to CKD and function are small or modest in persons free from acute stroke and dementia. However, HD and KT can result in major impairment. We discuss needed controls, the greater demand on controls after the start of $\mathrm{HD}$ and $\mathrm{KT}$, and suggest that mechanisms intervening relations between hypertension, or diabetes, and cognitive performance may be similar to those intervening between hypertension and cognitive performance and the hypertension and diabetes literature on cognition provides a good model for the study of early stage kidney disease and cognitive ability. We posit that the mechanisms linking CKD and cognition may be similar to those linking hypertension or diabetes to cognition. We identify the need for more studies with multiple cognitive test batteries, measures of every-day cognitive abilities relevant to patient understanding of the disease and treatments, and more studies with prevalent and incident dementia outcomes. Descriptors: kidney disease, chronic kidney disease, cognitive function, dementia and cardiovascular risk factors.
\end{abstract}


Table 1. Common predictor variables in studies of renal disease and cognitive performance

\begin{tabular}{|c|c|c|}
\hline Predictor & Metric or type of measurement & Type of variable \\
\hline $\begin{array}{l}\text { Uremic patient }{ }^{1} \text { vs. controls } \\
\text { eGFR }^{2} \\
\text { Serum creatinine (sCR) } \\
\text { Stage of kidney disease }\end{array}$ & $\begin{array}{l}\text { diagnostic criteria } \\
\mathrm{ml} / \mathrm{min} / 1.73 \mathrm{~m}^{2} \text { body surface } \\
\mathrm{mg} / \mathrm{dl} \text { or } \mu \mathrm{mol} / \mathrm{l} \\
\text { standard diagnostic criteria }\end{array}$ & $\begin{array}{l}\text { categorical } \\
\text { categorical }^{4} \text { or continuous } \\
\text { continuous } \\
\text { categorical }\end{array}$ \\
\hline
\end{tabular}

\footnotetext{
${ }^{1}$ Uremia defined as the accumulation of urinary waste products in the urine or the constellation of signs and symptoms indicating kidney disease or failure.

${ }^{2}$ eGFR can be estimated via different formulae: modification of diet in renal disease (MDRD) study equation; chronic kidney disease epidemiology collaboration (CKD-EPI) equation; Mayo Clinic Quadratic equation.

${ }^{3}$ See reference 5 for definitions and criteria.

${ }^{4}$ Studies often use eGFR $\geq 60\left(\mathrm{ml} / \mathrm{min} / 1.73 \mathrm{~m}^{2}\right)$ versus $<60$, or, for example, normal ( $\left.\geq 90\right)$; mildly decreased (60 to 89$)$; moderate CKD (30-59), severe CKD (15 to 29$)$ and kidney failure $(<15)$, or clinical criteria, tertiles, quartiles, quintiles etc.

${ }^{5}$ Continuously distributed such as eGFR in units $\left(\mathrm{ml} / \mathrm{min} / 1.73 \mathrm{~m}^{2}\right)$ or $\mathrm{sCR}$ in units $(1 \mathrm{mg} / \mathrm{dl})$ expressed as $1 /$ sCR due to skew [e.g. 26].
}

A new case of dementia occurs every 4 seconds worldwide, which is equivalent to 7.7 million cases each year, and mild cognitive impairment is even more prevalent [1]. Chronic kidney disease (CKD) is a risk factor (RF) for dementia and cognitive decline [2,3-5]. Cognitive impairment detracts from quality of life and is a risk factor for dialysis-related mortality [6]. In this brief review we summarize the literature on $\mathrm{CKD}$ in relation to cognitive function, discuss intervening mechanisms, and comment on some methodological issues, but refer the reader to other reviews of the many studies comparing treatments such as hemodialysis (HD), peritoneal dialysis (PD) and transplantation. We emphasize a pretreatment stage of CKD, but include studies examining modest to severe CKD.

\section{Renal Functioning Predictors of Cognitive Function}

Renal disease is well-defined in previous reviews $[2,3,5,7]$. Table 1 summarizes commonly used predictor variables in cognitive studies and the measurement metrics used to define them. Common predictors are estimated glomerular filtration rate (eGFR), serum creatinine (sCR) and far less commonly stages of renal disease [2] involving measures such a proteinuria, biopsy or structural imaging. 


\section{Cognitive Outcomes in Renal Studies}

A previous review provides a list of tests commonly used in the renal literature [3] and other reviews illustrate how multiple tests should be used where the goal is to infer the locus of brain impairment from one or more specific cognitive deficits $[8,9]$. Studies designed to examine which abilities do and do not relate to a disease must examine a wide range of different abilities [8,9]. Definitions of terms used in the psychometric literature are given in table 2. Outcome variables can be dichotomous (i.e. dementia, impairment, deficit), ordinal categories of performance level, or continuously distributed test scores representing performance level. We use the term cognitive impairment only if this cognitive status has been established by clinical criteria, i.e. neuropsychological (NP) evaluation and/or normative data. The term deficit is used as a comparative term indicating a lower average level of performance relative to a reference group or groups. The term decline is only used for longitudinal change in performance.

\section{Overview: End-Stage Renal Disease and Treatment}

We refer the reader to previous reviews $[2,3,5]$ for a summary of this literature. However, it is important to note that an estimated 70\% of HD patients over age 55 exhibit moderate-to-severe cognitive impairment [5] with a similar prevalence for PD patients [10]. Griva et al. [6] reported that two-thirds of a community-dwelling sample of $145 \mathrm{PD}$, home dialysis and in-center $\mathrm{HD}$ patients in London, UK, suffered from what the authors defined as mild or moderate cognitive impairment: 1.00-1.99 and 2-2.99 SD below the mean, respectively. We agree with Murray and Knopman [5] that performance 2.00 SD below the mean ( $2 \%$ of the population fall here) is not moderate, but is reflective of clinically significant cognitive dysfunction. Comprehensive reviews of this literature indicate that $\mathrm{HD}, \mathrm{PD}$ and transplantation are associated with wide ranging deficits in attention, memory, speed of performance, and components of executive functioning (EF) [5], although it is clear that adverse cognitive outcomes are attenuated when cognitive testing is timed properly in relation to dialysis treatment [2].

There have been few studies of practical everyday cognitive tasks and kidney disease. Numeracy skills are critical to advance planning necessary to comply with treatment regimens and disease understanding [11]. Numeracy refers to the degree that one can apply statistical, graphical and numerical skills in such a way as to effectively understand and comply with health information [11]. Abdel-Kader et al. [11] found that the majority of 187 end-stage renal disease 
Table 2. Definitions of terms used in this review

\begin{tabular}{|c|c|}
\hline Term & Definition \\
\hline Construct & The theoretical mental process that tests attempt to measure or index. \\
\hline Decline & Change in performance level from better to worse over time. \\
\hline Deficit & $\begin{array}{l}\text { A relative decrement in performance that does not rise to the level of } \\
\text { impairment, e.g. mean level of performance in a group is lower than mean } \\
\text { level of performance in another group, but individual differences in } \\
\text { performance may overlap among groups. }\end{array}$ \\
\hline Dementia & $\begin{array}{l}\text { A progressive cognitive impairment characterized by decline in memory ability } \\
\text { and impairment in one or more other cognitive domains, e.g., language, orien- } \\
\text { tation, reasoning, attention and EF. Represents a decline from a previous level } \\
\text { of functioning and interferes with activities of daily living and independence. } \\
\mathrm{AD} \text { is the most common form and a major risk factor is amnestic } \mathrm{MCl} \text {. }\end{array}$ \\
\hline Domain & $\begin{array}{l}\text { A composite set of skills measured (indexed) by more than one test of specific } \\
\text { ability as may be identified by factor analysis. }\end{array}$ \\
\hline Everyday ability & $\begin{array}{l}\text { A test that measures real-life activities such as map reading, check balancing, } \\
\text { following directions, organizing medications. }\end{array}$ \\
\hline Executive function & $\begin{array}{l}\text { The ability to anticipate, plan and organize and to reject old inappropriate } \\
\text { responses for new appropriate responses when confronted with a new } \\
\text { problem. Difficult to separate from fluid intelligence and often and } \\
\text { erroneously used as isomorphic with frontal lobe function, although frontal } \\
\text { lobe damage is associated with poorer EF. }\end{array}$ \\
\hline Fluid intelligence & $\begin{array}{l}\text { Ability with regard to dealing with new and novel tasks as opposed to } \\
\text { crystallized (verbal intelligence) ability, often with demands on speed of } \\
\text { performance. Many reviews of the literature have emphasized the extreme } \\
\text { difficulty of separating fluid intelligence from EF given their significant overlap } \\
\text { in abilities measured [9] }\end{array}$ \\
\hline Global ability & $\begin{array}{l}\text { Overall ability which is the synergistic combination of specific abilities, e.g. } \\
\text { overall score on an intelligence test. }\end{array}$ \\
\hline Impairment & $\begin{array}{l}\text { Poor performance reaching a clinically important level of deficit as defined by } \\
\text { neuropsychological assessment and/or normative data. }\end{array}$ \\
\hline Impurity & Failure of a test to measure only abilities it was designed to measure. \\
\hline $\begin{array}{l}\text { Level of } \\
\text { performance }\end{array}$ & $\begin{array}{l}\text { An average or median level of performance based on the entire distribution of } \\
\text { test scores or normative data. }\end{array}$ \\
\hline Mental status & $\begin{array}{l}\text { Ability measured by screening measures such as the Mini Mental Status } \\
\text { Examination (MMSE), often described as a test of global ability but lacking in } \\
\text { sensitivity and specificity relative to intelligence test measures. }\end{array}$ \\
\hline $\begin{array}{l}\text { Mild cognitive } \\
\text { impairment }\end{array}$ & $\begin{array}{l}\text { Mild cognitive impairment is a level of performance that indicates decline from } \\
\text { a previous level of performance and impairment by clinical/normative criteria, } \\
\text { but does not rise to the level of dementia. Individuals with mild cognitive } \\
\text { impairment typically remain in the community and do not necessarily exhibit } \\
\text { general intellectual decline. There are at least } 30 \text { different formal clinical } \\
\text { definitions in the literature. }\end{array}$ \\
\hline
\end{tabular}


Table 2. Continued

\begin{tabular}{ll}
\hline Term & Definition \\
\hline Short form & $\begin{array}{l}\text { A shorter form of a test designed to retain validity and reliability but normally } \\
\text { looses both to some extent. }\end{array}$ \\
\hline Specific ability & $\begin{array}{l}\text { Ability in a relatively narrow range of specialized functioning as opposed to } \\
\text { global cognitive ability or general intelligence. }\end{array}$ \\
\hline $\begin{array}{l}\text { Vascular dementia } \\
(\text { VaD) }\end{array}$ & $\begin{array}{l}\text { Memory decline may be present but not necessarily predominant and other } \\
\text { cognitive domains are affected early in the disease process and in the MCl that } \\
\text { precedes it. Progress of VaD is more varied over time than is the progress of } \\
\text { AD and a history of CVD risk factors and events are common. AD has a vascular } \\
\text { component and mixed dementias are common. }\end{array}$ \\
\hline
\end{tabular}

$($ ESRD) patients (mean age $=52$ years) exhibited low numeric efficiency on a 3 -item scale. Grubbs et al. [12] reported a 32.3\% prevalence of inadequate health care literacy in a sample of 62 dialysis patients. Gelb and colleagues [13], in a study of 108 kidney transplant recipients, reported that lower levels of performance on everyday problem-solving tests and number of depressive symptoms were associated with poor medication adherence, but found no association with multiple NP measures and adherence. These studies were not prospective and thus the direction of these associations needs to be defined in future studies.

In summary, the history of cognitive deficit and impairment begins prior to the transition to ESRD [5]. Once ESRD status has been reached and dialysis has begun, the demands on design and control become increasingly complex and thus the early or pre-treatment stages of CKD provide an important window of investigation.

\section{Cross-Sectional Community-Based Studies}

We have chosen to focus on the community-based studies given the very much larger samples, statistical adjustment for CVD and absence of sample bias introduced by multiple exclusions in order control for differences in health factors among uremic samples, healthy controls and patient groups.

Table 5 summarizes methodological detail and results for the communitybased studies which began to appear in 2005. Earlier investigations emphasized case-control type studies that compared uremic patients to other diagnostic groups, e.g. medical and psychiatric patients or healthy controls [2]. A major review of this case-control literature [2] indicates that uremic patients, compared to general medical and psychiatric groups, performed better on measures 
of motor speed, auditory alertness and crystallized intelligence and performed more poorly on measures of cognitive flexibility and other components of EF, verbal memory and learning, visual attention and fluid intelligence. In 3 of the case-control studies reviewed by Koushik et al. [2], levels of performance were not below average when compared to normative data. In some case-control studies exclusion for health factors were extensive [e.g.14], but often the major controls were for age, education, and sex [2].

In each of the community-based studies (table 3 ) there were controls (exclusion or adjustment) for demographic variables, CVD risk factors, or health factors, and other confounders. Estimated eGFR levels $<60$ versus $\geq 60$ were associated with deficits in global cognitive performance. Studies prior to 2009 reported that higher levels of eGFR were associated with deficits in language, memory, components of $\mathrm{EF}[15,16]$, learning and concentration [15], visual attention [15], psychomotor efficiency and processing speed [17], and global impairment on a telephone interview scale [18]. While sample sizes were impressive, the cognitive batteries were limited, sometimes involving only one or a few tests.

To address this issue, Elias et al. [19] using the Maine Syracuse Longitudinal Study (MSLS), employed 923 dementia-free community-dwelling individuals and 19 widely-used clinical cognitive tests in a factor analysis leading to the identification of the following outcome variables: (1) a global composite test score, (2) four composite scores or factors: visual-spatial organization and memory, scanning and tracking (a component of executive function), verbal memory, and working memory, and (3) a single measure of abstract reasoning (WAIS similarities) which loaded with approximately equal strength on each composite. Persons undergoing dialysis $(n=4)$ and/or diagnosed with dementia $(n=9)$ were excluded. For an analysis adjusting for demographic factors, CVD, and acute stroke, higher $\mathrm{sCR}$ values were associated with lower levels of performance for global performance, verbal episodic memory and scanning and tracking. For example increments in creatinine of $2 \mathrm{mg} / \mathrm{dl}$ were associated with a decrement of $0.12 \mathrm{SD}$ in performance level. Moreover, the odds ratios (ORs) associated with poor global performance (defined as the lowest quartile of the distribution of test scores) were $\mathrm{OR}=2.27$ with control for age, sex, education, and race and $\mathrm{OR}=$ 1.97 with additional adjustment for CVD and stroke.

In summary, community-based, large sample, cross-sectional studies support the generalization that mild and modest kidney disease is related to modest deficits in multiple cognitive abilities. As in the hypertension literature, crystallized intellect appears to be spared in studies of dementia-free samples [19]. The limitation of each of these studies is that they were cross-sectional and only two studies specifically reported excluding of dialysis patients $[19,20]$ or those with eGFR $<30$ [15]. 
Table 3. Community-based studies published after 2004 arranged by date of publication

\begin{tabular}{|c|c|c|c|c|}
\hline Authors & Design & Outcomes & Control or adjustment & $\begin{array}{l}\text { Summary of } \\
\text { Findings }\end{array}$ \\
\hline $\begin{array}{l}\text { Kurella et al. } \\
\text { [16] (2005) }\end{array}$ & $\begin{array}{l}1,105 \text { community-dwelling } \\
\text { postmenopausal women }(<80 \\
\text { years) with established corona- } \\
\text { ry artery disease (no hysterec- } \\
\text { tomy) enrolled in the Estrogen/ } \\
\text { Progestin Replacement Study. } \\
\text { CKD estimated using eGFR as } \\
\text { mild ( } 45-59), \text { moderate ( } 30-44) \\
\text { and severe (eGFR }<30) ; \text { eGFR } \\
\geq 60 \text { was the reference group. }\end{array}$ & $\begin{array}{l}\text { Multiple tests } \\
\text { including 3MS, Trail } \\
\text { Making Part B, } \\
\text { Boston Naming, } \\
\text { Verbal Fluency, } \\
\text { Word List Memory } \\
\text { and Recall. }\end{array}$ & $\begin{array}{l}\text { Adjustment for age, } \\
\text { race, education, life- } \\
\text { style factors, stroke, } \\
\text { diabetes, and other } \\
\text { variables related to } \\
\text { kidney disease. }\end{array}$ & $\begin{array}{l}\text { eGFR was } \\
\text { associated with } \\
\text { deficits in global } \\
\text { cognition, executive } \\
\text { function, language, } \\
\text { and memory (15- } \\
25 \% \text { increment in } \\
\text { risk for deficit per } 10 \\
\mathrm{ml} / \mathrm{min} / 1.73 \mathrm{~m}^{2} \\
\text { decrement in eGFR. }\end{array}$ \\
\hline $\begin{array}{l}\text { Hailpern et al. } \\
\text { [15] (2007) } \\
\text { Level ex- } \\
\text { pressed as } \\
\text { quartiles, } \\
\text { referent } \\
\text { group is } \\
\text { quartile with } \\
\text { the poorest } \\
\text { performance. }\end{array}$ & $\begin{array}{l}\text { Younger, healthy and } \\
\text { ethnically diverse community- } \\
\text { based adults recruited from } \\
\text { the NHANES III (age range } \\
20-59 ; \text { N range } 4,721 \text { to } 4,865 \\
\text { depending on the test used). } \\
\text { Moderate CKD was defined as } \\
\text { eGFR } 30 \text { to } 59 \text { with eGFR > } 60 \\
\text { as the reference group. }\end{array}$ & $\begin{array}{l}\text { Simple visual-motor } \\
\text { reaction time, visual } \\
\text { attention and } \\
\text { learning and } \\
\text { concentration tests. }\end{array}$ & $\begin{array}{l}\text { Ordinal regression } \\
\text { analysis, adjustment for } \\
\text { demographic variables } \\
\text { and self-reported } \\
\text { health variables. } \\
\text { Diabetes excluded in } \\
\text { sensitivity analyses. }\end{array}$ & $\begin{array}{l}\text { Moderate CKD was } \\
\text { associated with } \\
\text { poorer learning and } \\
\text { concentration } \\
(\mathrm{OR}=2.4) \text { and visual } \\
\text { attention (OR }=2.7) \\
\text { when adjusted for } \\
\text { age, gender, } \\
\text { education, race, and } \\
\text { self-reported } \\
\text { general health and } \\
\text { other variables } \\
\text { related to CKD. }\end{array}$ \\
\hline $\begin{array}{l}\text { Jassal et al. } \\
\text { [17] (2008) } \\
\text { Performance } \\
\text { level (test } \\
\text { scores). }\end{array}$ & $\begin{array}{l}99 \text { uremic patients (mean age } \\
65, \text { with } 50 \%>65 \text { years) with } \\
\text { stage } 3-5 \text { kidney disease on } \\
\text { optimized medical treatment } \\
\text { at a predialysis clinic. Renal } \\
\text { function defined as eGFR } \\
\text { calculated as a continuously } \\
\text { distributed variable. }\end{array}$ & $\begin{array}{l}\text { Multiple cognitive } \\
\text { tests with } \\
\text { composite scores } \\
\text { measuring three } \\
\text { domains : attention } \\
\text { and working } \\
\text { memory; psycho- } \\
\text { motor efficiency } \\
\text { and processing } \\
\text { speed; learning } \\
\text { efficiency. }\end{array}$ & $\begin{array}{l}\text { Adjustment for age, } \\
\text { education and sex, } \\
\text { comorbid diseases, } \\
\text { hemoglobin, PTH, and } \\
\text { number of neurode- } \\
\text { pressor drugs. } \\
\text { antidepression medica- } \\
\text { tion, parathyroid disea- } \\
\text { ses. Sensitivity analysis } \\
\text { with ESPS. } \\
\text { Exclusions: head injury, } \\
\text { learning disabilities, } \\
\text { history of acute stroke } \\
\text { and TIA, and depressed } \\
\text { mood. }\end{array}$ & $\begin{array}{l}\text { Renal function } \\
\text { (eGFR) was related } \\
\text { to poorer perfor- } \\
\text { mance on test of } \\
\text { psychomotor effici- } \\
\text { ency and processing } \\
\text { speed with statisti- } \\
\text { cal adjustment for } \\
\text { covariates, but was } \\
\text { not associated with } \\
\text { performance scores } \\
\text { for attention and } \\
\text { working memory or } \\
\text { learning ability. }\end{array}$ \\
\hline $\begin{array}{l}\text { Kurella Tamu- } \\
\text { ra et al. [18] } \\
(2008)\end{array}$ & $\begin{array}{l}23,405 \text { community-dwelling } \\
\text { participants ( }>44 \text { years) from } \\
\text { the REGARDS Study. CKD } \\
\text { defined as }<60 \text {. eGFR in } 10-\mathrm{ml} / \\
\mathrm{min} / 1.73 \mathrm{~m}^{2} \text { increments. }\end{array}$ & $\begin{array}{l}\text { A six item } \\
\text { telephone } \\
\text { screening test with } \\
\text { cognitive } \\
\text { impairment (sic. } \\
\text { deficit) defined as a } \\
\text { score of }<4 \text {. }\end{array}$ & $\begin{array}{l}\text { Excluded eGFR }<10 \text {. } \\
\text { Adjusted for age, edu- } \\
\text { cation, sex, race, recru- } \\
\text { itment location, CVD } \\
\text { and CVD risk factors. }\end{array}$ & $\begin{array}{l}\text { CKD }<60 \text { was associ- } \\
\text { ated with higher } \\
\text { risk of cognitive } \\
\text { deficit }(\mathrm{OR}=1.23) . \\
\text { Each } 1-\mathrm{ml} / \text { min } 1.73 \\
\mathrm{~m}^{2} \text { was associated } \\
\text { with an increment } \\
\text { in cognitive impair- } \\
\text { ment }(\mathrm{OR}=1.11) .\end{array}$ \\
\hline
\end{tabular}


Table 3. Continued

\begin{tabular}{|c|c|c|c|c|}
\hline Authors & Design & Outcomes & Control or adjustment & $\begin{array}{l}\text { Summary of } \\
\text { Findings }\end{array}$ \\
\hline $\begin{array}{l}\text { Elias et al. } \\
{[19]^{1} \text { (2009) }} \\
\text { Performance } \\
\text { decrement } \\
\text { defined as } \\
\text { the lowest } \\
\text { quartile and } \\
\text { also perfor- } \\
\text { mance level. }\end{array}$ & $\begin{array}{l}923 \text { community dwelling } \\
\text { participants (>40 years of age); } \\
\text { comparisons between eGFR } \\
>60 \text { and } \leq 60 \text {; increment in sCR } \\
\text { from } 1 \text { to } 2 \mathrm{mg} / \mathrm{dl} \text {, and } 1 / \mathrm{sCR} \text { as } \\
\text { a continuously distributed } \\
\text { variable. }\end{array}$ & $\begin{array}{l}\text { Based on } 19 \text { tests } \\
\text { submitted to factor } \\
\text { analysis. Composite } \\
\text { scores were formed } \\
\text { for verbal episodic } \\
\text { memory (VEM), } \\
\text { visual-spatial } \\
\text { memory and } \\
\text { organization, } \\
\text { (VSOM) scanning } \\
\text { and tracking (ST), } \\
\text { working memory } \\
\text { (WM), and a global } \\
\text { composite of all } \\
\text { scores. }\end{array}$ & $\begin{array}{l}\text { Adjusted for age, } \\
\text { education, sex, race, } \\
\text { diabetes, systolic blood } \\
\text { pressure, BMI, smoking, } \\
\text { HDL and stroke and } \\
\text { other risk factors in } \\
\text { sensitivity analyses. } \\
\text { Exclusions: dialysis, } \\
\text { dementia, < } 40 \text { years of } \\
\text { age. }\end{array}$ & $\begin{array}{l}\text { Comparisons of } \\
\text { persons with eGFR } \\
\geq 60 \text { with eGFR }<60 \\
\text { indicated } \\
\text { decrement for the } \\
\text { latter group for the } \\
\text { global composite, } \\
\text { OR }=1.25, \text { VSOM, } \\
\text { OR = 1.88), and ST } \\
\text { (components of EF), } \\
\text { OR = 1.56. Same } \\
\text { associations for } \\
\text { performance level } \\
\text { outcomes. } \\
\text { Higher levels of } \\
\text { creatinine were } \\
\text { associated with } \\
\text { lower levels of } \\
\text { performance on the } \\
\text { global composite, } \\
\text { WM, and ST. }\end{array}$ \\
\hline
\end{tabular}

\section{Longitudinal Studies}

Longitudinal studies of community-based samples after 2004 are summarized in table 4 . These studies measure change in cognitive functioning over time. Studies are arranged by outcomes: (1) level of cognitive performance, (2) binary levels of performance where decline in performance is based on poor performance at follow-up defined arbitrarily or in terms of normative data, and (3) binary or gradations of certainty with regard to probable dementia. The first two categories are important to the third because lower cognitive performance in persons free from acute stroke and dementia is a risk factor for dementia [21]. The studies cited have relatively good controls as defined by adjustment for age, sex, education, and race, where relevant, and extended models which consider health variables, cardiovascular risk factors or events (e.g. stroke). Table 5 provides a check-list summary of results for papers summarized in table 4 . Each of the studies $[20,22-28]$ reported that baseline levels for at least one predictor was related to cognitive decline, impairment or dementia, except for Slinin et al. [29] who obtained negative results with adjustment for age. Davey et al. [4] with the smallest longitudinal sample $(n=590)$, but with a comprehensive cognitive test battery, did not find longitudinal change in cognitive performance from base- 
Table 4. Longitudinal studies of relations between kidney function and cognitive function organized by type of outcome (see italics): levels, impairment, dementia

\begin{tabular}{|c|c|c|}
\hline $\begin{array}{l}\text { Authors, outcome and } \\
\text { time to follow-up }\end{array}$ & Predictor(s) & Controls: adjustments or exclusions \\
\hline $\begin{array}{l}\text { Buchman et al. [22] } \\
\text { (2009) } \\
\text { Decline in performance } \\
\text { over } 3.4 \text { years. }\end{array}$ & $\begin{array}{l}\text { Continuous eGFR (MDRD) at } \\
\text { baseline and trichotomized } \\
\text { impaired kidney function at } \\
\text { baseline defined as }<45,>45 \text { to } \\
<60,>60 \text {. }\end{array}$ & $\begin{array}{l}\text { eGFR at baseline, age, sex, education, BMI, } \\
\text { hemoglobin, physical activity, social activi- } \\
\text { ty, vascular risk factors, vascular diseases, } \\
\text { depressive symptoms. } \\
\text { Exclusions: dementia. }\end{array}$ \\
\hline $\begin{array}{l}\text { Jassal et al. [24] (2010) } \\
\text { Annual decline in perfor- } \\
\text { mance level over mean } \\
\text { follow-up of } 6.6 \text { years. }\end{array}$ & $\begin{array}{l}\text { eGFR categorized as } \geq 60 \text { or }<60 \\
\text { and albuminuria ( } A C R \geq 30 \\
\mathrm{mg} / \mathrm{g} \text { ) versus no albuminuria. }\end{array}$ & $\begin{array}{l}\text { Stratified by sex. } \\
\text { Covariates: age, SBP, HbA1C, education, } \\
\text { strenuous exercise, alcohol consumption, } \\
\text { current estrogen for women, eGFR, de- } \\
\text { pressed mood, antihypertensive meds, } \\
\text { lipid-lowering meds, } \\
\text { Exclusions: }<50 \text { years of age, stroke. }\end{array}$ \\
\hline $\begin{array}{l}\text { Wang et al. [28] (2010) } \\
\text { Decline in performance } \\
\text { over } 4 \text { years. (yes/no) in } \\
\text { relation to baseline } \\
\text { eGFR. }\end{array}$ & $\begin{array}{l}\text { Categories of eGFR: } \geq 90 \text { (refe- } \\
\text { rence), } 60--89,30-59 ; \text { conti- } \\
\text { nuous eGFR in secondary analy- } \\
\text { ses; albuminuria defined as } \geq 25 \\
\mathrm{mg} / \mathrm{g} \text { for males and } \geq 17 \mathrm{mg} / \mathrm{g} \\
\text { for females. }\end{array}$ & $\begin{array}{l}\text { Basic: age, sex, education, BMI Additional: } \\
\text { SBP, diabetes, urinary ACR. } \\
\text { Exclusions: stroke. }\end{array}$ \\
\hline $\begin{array}{l}\text { Davey et al. }[4] \\
\text { Decline in level of perfor- } \\
\text { mance (over } 4-5 \text { years). }\end{array}$ & $\begin{array}{l}\text { Continuously distributed eGFR } \\
\text { and } 1 / \mathrm{sCR} \text { and change in eGFR } \\
\text { baseline to follow-up. }\end{array}$ & $\begin{array}{l}\text { Basic controls: age, education, sex race/ } \\
\text { ethnicity, eGFR at baseline. Additional } \\
\text { controls: diabetes, depressed mood, alco- } \\
\text { hol consumption, diabetes and hypertensi- } \\
\text { on, APOE genotype, smoking, and cardio- } \\
\text { vascular disease. } \\
\text { Exclusions, stroke at baseline dementia } \\
\text { and renal dialysis. }\end{array}$ \\
\hline
\end{tabular}

Kurella et al. [25] (2005) Incident impairment (yes/ no) with follow-up at 2 and 4 years.
Categories of eGFR: $\geq 60$ (reference), $45-59,<45$.

Also used estimated creatinine clearance (Cockroft-Gault) and gender-specific creatinine cut-points (top 1 and 10\% of distributions). eGFR (MDRD) categories, $\geq 60$ : 45-59 (mild CKD), <45 (moderate CKD).
Slinin et al. [29] (2008) Incident impairment (yes/ no) in follow-up 4.6 years.

\section{Basic: age, race, gender, education} Additional: baseline CVD, diabetes, BP, lipids, inflammatory markers, hematocrit concentration, incident stroke

Exclusions: baseline cognitive impairment; ADL difficulties; life-threatening illness; intention of moving before follow-up.

Basic: age, education, race

Additional: health status, IADL impairments, alcohol use, diabetes, hypertension, stroke, CVD, BMI, PAD Exclusions: unable to walk; bilateral hip replacement; severe medical conditions, dialysis excluded in secondary analyses.

\section{Basic: age, sex}

Additional: depression, physical activity, alcohol, diabetes, IHD/stroke, hyperlipidemia, hypertension, smoking

Exclusions: cognitive impairment at baseline; CKD at baseline in secondary analyses. 


Sample
886 community-dwelling
participants (mean age $=80.6$ )
from the Rush Memory and
Aging Project who participa-
ted in both baseline and
follow-up analyses.

759 community dwelling men and women (mean age $=74.9$ years) at baseline who returned for repeat testing.
Cognitive tests or diagnostic category

5 subscale composites and a global composite derived from 19 individual measures. Subscales were: episodic memory, semantic memory, working memory, perceptual speed, visuospatial abilities.

MMSE, Trails B, and Animals Naming Category Fluency test performance levels, both continuous and using cut points.
Major statistically significant findings $^{1}$

Lower eGFR and impaired kidney function associated with rate of decline in global composite, episodic memory, semantic memory, and working memory.

For men but not women, baseline albuminuria, but not eGFR, was associated with decline in MMSE and category fluency scores with adjustment for all covariates.

\section{1,243 community-based Chinese participants ( $\geq 40$ years of age) with an eGFR $>30$; and 66 cases of during a 4-year follow-up.}

\section{A fall in MMSE of $\geq 2$ points from} baseline was defined as cognitive decline.
Relative to the reference group, risk of decline was higher for those with eGFR of 30-59.
590 Maine-Syracuse Longitudinal Study participants who participated at baseline and follow-up.
Decline in performance level for abstract reasoning and 4 major domains of functioning based on factor analysis of 19 separate test scores.
Baseline levels of eGFR and 1/sCR were unrelated to longitudinal change but change in renal function (eGFR) longitudinally was associated with change in cognitive performance for the global composite, verbal memory composite, and Similarities with all controls employed.

eGFR levels $<60$ were associated with greater odds of cognitive impairment, with adjustment for the full model. Creatinine levels in the top 10 and $1 \%$ were associated with higher odds of cognitive impairment, with adjustment for the basic model.

Odds of incident impairment in relation to CKD was observed but was attenuated and not significant with adjustment for age.
3,722 community-based men ( $\geq 65$ years) from the Osteoporotic Fractures in Men Study who provided baseline and follow-up data.
3MS and Trails B

Impairment defined as an $3 \mathrm{MS}$ score $<80$ or decline $\geq 5$; or increase in Trails $B$ time $\geq 1$ SD above mean change.
(3) Mini-Mental State Ex $3 \mathrm{MS}>5$ at either follow-up exam.

\begin{tabular}{|c|c|c|}
\hline $\begin{array}{l}\text { 3,154 INVADE study partici- } \\
\text { pants (>54 years) ( } 396 \text { with } \\
\text { cognitive impairment at } \\
\text { baseline and } 194 \text { with inci- } \\
\text { dent cognitive impairment at } \\
\text { follow-up. }\end{array}$ & $\begin{array}{l}\text { Blessed Information Memory } \\
\text { Concentration Scale (6CIT). } \\
\text { A score }>7 \text { defined as } \\
\text { impairment. }\end{array}$ & $\begin{array}{l}\text { eGFR }<45 \text { associated with cognitive } \\
\text { impairment with adjustment for all } \\
\text { covariates. } \\
\text { With exclusion of CKD at baseline, } \\
\text { incident CKD (eGFR }<60 \text { ) was associa- } \\
\text { ted with incident cognitive impair- } \\
\text { ment (covariates not reported). }\end{array}$ \\
\hline
\end{tabular}


Table 4. Continued

\begin{tabular}{|c|c|c|}
\hline $\begin{array}{l}\text { Authors, outcome and } \\
\text { time to follow-up }\end{array}$ & Predictor(s) & Controls: adjustments or exclusions \\
\hline $\begin{array}{l}\text { Seliger et al. [27] (2004) } \\
\text { Incident dementia (AD } \\
\text { and VaD); follow-up } \\
\text { median } 6 \text { years. }\end{array}$ & $\begin{array}{l}\text { Primary: } 1 / \mathrm{sCR} \text {. } \\
\text { Secondary: renal insufficiency: } \\
\mathrm{sCR} \geq 1.3 \mathrm{mg} / \mathrm{dl} \text { for women and } \\
1.5 \mathrm{mg} / \mathrm{dl} \text { for men. }\end{array}$ & $\begin{array}{l}\text { Basic: adjustment for age, sex, race and } \\
\text { body weight. } \\
\text { Education, coronary heart disease, diabe- } \\
\text { tes, hypertension, smoking status, and } \\
\text { ApoE genotype; Exclusions: prevalent } \\
\text { dementia at baseline. }\end{array}$ \\
\hline $\begin{array}{l}\text { Helmer et al. [23] (2011) } \\
\text { Incident dementia (AD, } \\
\text { vascular) and change in } \\
\text { level of performance on } \\
\text { the MMSE; follow-up } \\
\text { median } 6.8 \text { years. }\end{array}$ & $\begin{array}{l}\text { eGFR (CKD-EPI) at baseline and } \\
\text { change in eGFR over time, } \\
\text { proteinuria. }\end{array}$ & $\begin{array}{l}\text { Basic: adjustment for study center, age, } \\
\text { sex, education, APOE genotype. } \\
\text { Additional: hypertension, CVD, stroke, high } \\
\text { lipid levels, diabetes, smoking, BMI, baseli- } \\
\text { ne eGFR. } \\
\text { Exclusions: prevalent dementia at baseline. }\end{array}$ \\
\hline
\end{tabular}

\begin{tabular}{lll}
\hline Sasaki et al. [26] (2011) & CKD present/absent based on & Age, sex, education, hypertension, diabe- \\
Incident dementia & eGFR and albuminuria. & $\begin{array}{l}\text { tes, dyslipidemia, ischemic heart disease, } \\
\text { anemia. }\end{array}$
\end{tabular}

${ }^{1}$ Negative results are not summarized (see variables column).

line to follow-up. However, a decline in renal function over time (indicated by eGFR or sCR) was related to a decline in global cognitive performance, verbal memory and abstract reasoning. Negative findings relative to decline in cognitive performance relative to baseline levels of renal function are not readily explained by study length or number of cognitive measures. Relative to other studies, Davey et al. [4] featured the largest number of cognitive outcomes and a fairly long follow-up of 4-5 years. But the sample was relatively well educated and change in renal function may be more sensitive in terms of cognitive change than baseline levels. Following 2,406 participants over 4 years, Helmer et al. [23] also found that change in renal function over 4 years but not baseline renal function was related to longitudinal decline (incident dementia).

None of the longitudinal studies used an everyday measure of cognitive performance or employed numeracy as a predictor or covariate and only 5 of the 16 studies summarized in tables 4 and 5 adjusted for clinical depression or depressed mood.

Obviously, there is a need for more studies with comprehensive test batteries, longer longitudinal follow-up periods and stratification by education level and/or numeracy skill, and with explicit exclusion of renal dialysis patients. Yet considering these studies collectively, it is clear that depending on severity of renal disease and the general health of the study population, various indices of 


\begin{tabular}{|c|c|c|}
\hline Sample & $\begin{array}{l}\text { Cognitive tests or diagnostic } \\
\text { category }\end{array}$ & $\begin{array}{l}\text { Major statistically significant } \\
\text { findings }^{1}\end{array}$ \\
\hline $\begin{array}{l}\text { 3,349 participants of the Car- } \\
\text { diovascular Health Cognition } \\
\text { Study (age }>64 \text { years). Inci- } \\
\text { dent dementia = } 477 \text { cases. } \\
\text { Stratification by health status } \\
\text { at baseline: poor, good and } \\
\text { excellent. }\end{array}$ & $\begin{array}{l}\text { Diagnosis of dementia based on } \\
\text { multiple test scores and clinical } \\
\text { review. Type of dementia assessed } \\
\text { with MRI. }\end{array}$ & $\begin{array}{l}\text { Associations between elevated creati- } \\
\text { nine and incident dementia, but only } \\
\text { for non- dementia participants in } \\
\text { good to excellent health at baseline; } \\
\text { higher } \mathrm{SCR} \text { associated with increased } \\
\text { risk of } \mathrm{VaD} \text {, but not 'pure' AD-type } \\
\text { dementia. }\end{array}$ \\
\hline $\begin{array}{l}\text { 7,839 participants of the } 3 C \\
\text { Study (baseline eGFR); } \\
\text { 2,382 multiple eGFR } \\
\text { 1,040 proteinuria } \\
\text { (age }>65 \text { years). }\end{array}$ & $\begin{array}{l}\text { Diagnosis of dementia; based on } \\
\text { NP examination and review by } \\
\text { neurologist (DSM-IV criteria). } \\
\text { Etiology based on NINCDS-ADR- } \\
\text { DA and NINDS-AIREN criteria. }\end{array}$ & $\begin{array}{l}\text { No increased risk of cognitive decline } \\
\text { or incident dementia in relation to } \\
\text { eGFR at baseline. However, eGFR } \\
\text { decline was associated with decline } \\
\text { in global cognition (MMSE) and eGFR } \\
\text { decline }>4 \text { /year and proteinuria were } \\
\text { related to increased risk for incident } \\
\text { vascular dementia (with adjustment } \\
\text { for extended covariate set). }\end{array}$ \\
\hline $\begin{array}{l}256 \text { community-dwelling } \\
\text { participants from the Osaki- } \\
\text { Tajiri Project (Northern Japan) } \\
\text { ( } \geq 65 \text { years). }\end{array}$ & $\begin{array}{l}\text { Dementia: NINCDS-ADRDA and } \\
\text { NINDS-AIREN criteria. }\end{array}$ & $\begin{array}{l}\text { Association between CKD and con- } \\
\text { version to dementia from a normal or } \\
\text { questionable state at baseline with } \\
\text { adjustment for all covariates. }\end{array}$ \\
\hline
\end{tabular}

CKD prevalence are related to decline in cognitive performance over time and dementia in samples over 65 years of age. What is not known from current studies is the prevalence, incidence or rate of cognitive decline prior to dementia.

It is encouraging to find that in the study of relatively well-educated nondemented community-based subjects, dialysis excluded, decline in performance levels over 4-5 years was modest and not such that they would interfere with understanding and adherence necessary to the treatment of renal disease [4].

\section{Mechanisms Relating Kidney Disease to Cognition}

Table 6 lists variables that may mediate between renal disease and cognitive function. One may hypothesize, among other models, direct paths in which $\mathrm{CKD}$ affects brain function and morphology and hence cognition. An alternative, and not mutually exclusive, possibility is that risk factors shared by brain and kidney lead to cognitive deficit, decline and impairment [30]. This parallel risk factor model is appealing because 'both kidney and brain are low resistance end organs and are exposed and re-exposed to high-volume blood flow though the cardiac cycle' [30, p. 5]. Thus the brain and kidney very likely share 
Table 5. Summary check sheet for essential methods and findings with eGFR serum creatinine, albuminuria as outcome variables with studies ordered as in table 4

\begin{tabular}{|c|c|c|c|c|c|c|c|c|c|}
\hline \multirow{2}{*}{$\begin{array}{l}\text { First } \\
\text { author }\end{array}$} & \multirow[t]{2}{*}{ eGFR } & \multirow{2}{*}{$\begin{array}{l}\text { Crea- } \\
\text { tinine }\end{array}$} & \multirow{2}{*}{$\begin{array}{l}\text { Albu- } \\
\text { minuria }\end{array}$} & \multirow{2}{*}{$\begin{array}{l}\text { MMSE/3MS } \\
\text { (Global) }\end{array}$} & \multirow{2}{*}{$\begin{array}{l}\text { Composite } \\
\text { of tests } \\
\text { (Global) }\end{array}$} & \multirow{2}{*}{$\begin{array}{l}\text { Number } \\
\text { of tests } \\
\text { used as } \\
\text { outcomes }\end{array}$} & \multirow[t]{2}{*}{ Dementia } & \multicolumn{2}{|c|}{ Decline on any test or incident dementia } \\
\hline & & & & & & & & $\begin{array}{l}\text { relative to } \\
\text { baseline renal } \\
\text { function }\end{array}$ & $\begin{array}{l}\text { relative to } \\
\text { change in } \\
\text { renal function }\end{array}$ \\
\hline Buchman & $\checkmark$ & & & $\checkmark$ & $\checkmark$ & 19 & & $\checkmark$ eGFR & \\
\hline Jassal & $\checkmark$ & & $\checkmark$ & $\checkmark$ & & 2 & & $\checkmark$ albuminuria male & \\
\hline Wang & $\checkmark$ & & $\checkmark$ & $\checkmark$ & & & & $\checkmark$ eGFR & \\
\hline Davey & $\checkmark$ & $\checkmark$ & & & $\checkmark$ & 19 & & & $\checkmark$ eGFR/sCR \\
\hline Kurella & $\checkmark$ & $\checkmark$ & & $\checkmark$ & & & & $\checkmark$ & \\
\hline Slinin & $\checkmark$ & & & $\checkmark$ & & 1 & & & \\
\hline Etgen ${ }^{1}$ & $\checkmark$ & & & & & 1 & & $\checkmark$ eGFR & \\
\hline Seliger ${ }^{2,3}$ & & $\checkmark$ & & & & & $\checkmark$ & $\checkmark$ eGFR/sCR & \\
\hline Helmer & $\checkmark$ & & & & & & $\checkmark$ & & $\checkmark$ \\
\hline Sasaki & $\checkmark$ & & & & & & $\checkmark$ & $\checkmark$ & \\
\hline
\end{tabular}

${ }^{1}$ Based on Cockroft-Gault formula, standardized for body surface area.

${ }^{2}$ Renal insufficiency, defined differently for men $(1.5 \mathrm{mg} / \mathrm{dl})$ and women $(1.3 \mathrm{mg} / \mathrm{dl})$, was related incident dementia.

${ }^{3}$ Only for dementia-free persons in good or excellent health at baseline.

Table 6. Some candidate mechanisms mediating between kidney disease and cognitive functioning on order of discussion in text ${ }^{1}$

CVD risk factors Hypertension, chronic hypotension, diabetes mellitus, hyperlipidemia, cardiovascular disease, including myocardial infarction, arterial fibrillation, cigarette smoking, elevated homocysteine, hemostatic abnormalities, hypercoagulation, oxidative stress, inflammation, acute stroke

Biologic intrinsic Vascular changes in brain; anemia, white matter lesions, anemia, cortical atrophy, hyperparathyroidism, microalbuminuria, subclinical atherosclerosis

Psychosocial/treatment Clinical depression and depressed mood and other psychosocial variables, polypharmacy, malnutrition

Dialysis-related Hypotensive episodes, chronic microembolism, subclinical increases in brain edema, acute stroke, silent and asymptomatic stroke, hemodynamic changes and fluid shifts, microalbuminuria, recurrent cerebral ischemia, acute dynamic cardiovascular changes, lacunar infarcts, microbleeds

${ }^{1}$ See reviews of the literature including references $3-5$.

common risk factors for cognitive deficit and impairment. It is clear that the issue of mediating variables becomes complex once treatment is initiated for ESRD. Thus we refer the reader to a comprehensive model by Murray and Knopman [5] and in table 6 summarize the many candidate mechanisms. In pretreatment forms of renal disease it makes some sense that the search for 
mechanisms should begin with the strongest risk factors for kidney disease, i.e. hypertension and diabetes. However, few if any mediation studies have been undertaken.

\section{Methodological Issues}

\section{Controls}

Controls for age, education, sex and, where relevant, race and ethnic composition are imperative, and controls for prevalent CVD risk factors, including depressed mood or clinical depression, and CVD events (e.g. acute stroke) are very important. But inspection of table 6 indicates that many other potential confounders exist even where the focus is pre-ESRD kidney disease. Polypharmacy is highly prevalent in the elderly. Moreover, many social psychological factors that are correlated with renal disease are especially important when patient groups or nonpatients are employed as control groups.

\section{Cognitive Measurement}

The finding that renal disease is related to multiple cognitive abilities, with few exceptions (e.g. over-learned crystallized intelligence), may be related to the fact that renal disease has a diffuse effect on brain function. However, it is important to recognize that the clinical cognitive tests traditionally employed in research on disease are impure, i.e., they measure a mixture of intended and untended cognitive constructs. Clinical cognitive tests are highly correlated with each other and with tests of general intellectual functioning [9]. There are two solutions: (1) factor analyses that identify theoreticallyrelevant cognitive domains [e.g. 19], and (2) utilization of more precise information processing tasks [9]. The latter method increases measurement purity but also increases performance difficulty for poorly educated study participants, makes significant demands on study time, and is less clinically interpretable.

\section{Clinical Implications}

In general, predialysis and pretransplant levels of cognitive deficit are relatively modest in well cared for and relatively highly educated, dementiaand stroke-free community samples [e.g. 19, 22]. This is good news and suggests that intervention might possibly be effective in preventing or delaying more serious ESRD and ESRD treatment-related cognitive deficit and impairment [5]. This conclusion is tentative pending more studies and clinical trials. 


\section{Conclusion}

Prior to ESRD and treatment, kidney disease can result in global and multiple, specific-cognitive deficits, often mild, but sometimes associated with dementia. Treatment methods are improving but the physiological consequences of treatment can lead to more severe deficit. Biological factors intrinsic to renal disease, psychosocial factors, and polypharmacy are candidate intervening mechanisms, but formal studies identifying mediators between mild and modest levels of kidney disease and cognition have not been done.

We are starting down the path of a complex and challenging area of research and have a long way to go. We are in a descriptive phase of research, albeit we need more studies with comprehensive batteries of cognitive tests and tests of everyday cognitive function. To our knowledge, there have been no randomized-to-treatment clinical trials addressing improvement in cognitive performance with treatment for CVD risk factors. The clinical trial literature on hypertension provides a good model for this important next step.

\section{Acknowledgements}

This review was supported, in part, by grants R01HL67358 and R01HL081290 from the National Heart Lung and Blood Institute, National Institutes of Health (USA).

\section{References}

1 Alzheimer's Association: 2012 Alzheimer's disease facts and figures. Alzheimers Dement 2012;8:131-168.

2 Koushik NS, McArthur SF, Baird AD: Adult chronic kidney disease: neurocognition in chronic renal failure. Neuropsychol Rev 2010;20:33-51.

-3 Etgen T, Chonchol M, Förstl H, Sander D: Chronic kidney disease and cognitive impairment: a systematic review and meta-analysis. Am J Nephrol 2012;35:474-482.

4 Davey A, Elias MF, Robbins MA, Seliger SL, Dore GA: Decline in renal functioning is associated with longitudinal decline in global cognitive functioning, abstract reasoning and verbal memory. Nephrol Dial Transplant 2012: Advance online publication. doi: $10.1093 / \mathrm{ndt} / \mathrm{gfs} 470$.

5 Murray AM, Knopman DS: Cognitive impairment in CKD: no longer an occult burden. Am J Kidney Dis 2010;56:615-618.
6 Griva K, Stygall J, Hankins M, Davenport A, Harrison M, Newman SP: Cognitive impairment and 7-year mortality in dialysis patients. Am J Kidney Dis 2010;56:693-703.

7 National Kidney Foundation: Frequently asked questions about GFR estimates. NY, NY www.kidney.org.

$>8$ Elias MF, Goodell AL, Dore GA: Hypertension and cognitive functioning: a perspective in historical context. Hypertension 2012;60: 260-268.

9 Rabbit P (ed): Methodology of Frontal and Executive Function. Hove, East Essex, UK: Psychology Press, 1998.

10 Radic J, Ljutic D, Radic M, Kovacid V, Sain M, Cukovic KD: The possible impact of dialysis modality on cognitive function in chronic dialysis patients. Neth J Med 2010;63: 153-157. 
11 Abdel-Kader K, Dew MA, Bhatnagar M, Argyropoulos C, Karpov I, Switzer G, Unruh ML: Numeracy skills in CKD: correlates and outcomes. Clin J Am Soc Nephrol 2010;5: 1566-1573.

12 Grubbs V, Gregorich SE, Perez-Stable EJ, Hsu CY: Health literacy and access to kidney transplantation. Clin J Am Soc Nephrol 2009;4: 195-200.

13 Gelb SR, Shapiro RJ, Thornton WJ: Predicting medication adherence and employment status following kidney transplant: the relative utility of traditional and everyday cognitive approaches. Neuropsychology 2010;24:514-526.

14 Thornton WL, Shapiro RJ, Deria S, Gelb S, Hill A: Differential impact of age on verbal memory and executive functioning in chronic kidney disease. J Int Neuropsychol Soc 2007;13:344-353.

$\checkmark 15$ Hailpern SM, Melamed ML, Cohen HW, Hostetter TH: Moderate chronic kidney disease and cognitive function in adults 20 to 59 years of age: Third National Health and $\mathrm{Nu}$ trition Examination Survey (NHANES III). J Am Soc Nephrol 2007;18:2205-2213.

16 Kurella M, Yaffe K, Shlipak MG, Wenger NK, Chertow GM: Chronic kidney disease and cognitive impairment in menopausal women. Am J Kidney Dis 2005;45:66-76.

17 Jassal SV, Roscoe J, LeBlanc D, Devins GM, Rourke S: Differential impairment of psychomotor efficiency and processing speed in patients with chronic kidney disease. Int Urol Nephrol 2008;40:849-854.

-18 Kurella Tamura M, Wadley V, Yaffe K, McKlure LA, Howard G, Go R, Warnock DG, McClellan $\mathrm{W}$ : Kidney function and cognitive impairment in US adults: the Reasons for Geographic and Racial Differences in Stroke (REGARDS) Study. Am J Kidney Dis 2008;52:227-234.

19 Elias MF, Elias PK, Seliger SL, Narsipur SS, Dore GA, Robbins MA: Chronic kidney disease, creatinine and cognitive functioning. Nephrol Dial Transplant 2009;24:2446-2452.

20 Etgen T, Sander D, Chonchol M, Briesenick C, Poppert H, Förstl H, Bickel H: Chronic kidney disease is associated with incident cognitive impairment in the elderly: the INVADE study. Nephrol Dial Transplant 2009; 24:3144-3150.

Merrill F. Elias

Department of Psychology, The University of Maine

5742 Little Hall

Orono, ME 04469 (USA)

E-Mail MFElias@maine.edu
21 Elias MF, Beiser A, Wolf PA, Au R, White RF, D'Agostino RB: The preclinical phase of Alzheimer disease: a 22-year prospective study of the Framingham Cohort. Arch Neurol 2000;57:808-813.

22 Buchman AS, Tanne D, Boyle PA, Shah RC, Leurgans SE, Bennett DA: Kidney function is associated with the rate of cognitive decline in the elderly. Neurology 2009;73:920-927.

23 Helmer C, Stengel B, Metzger M, Froissart M, Massy ZA, Tzourio C, Berr C, Dartigues JF: Chronic kidney disease, cognitive decline, and incident dementia: the 3C Study. Neurology 2011;77:2043-2051.

24 Jassal S, Kritz-Silverstein D, Barrett-Connor E: A prospective study of albuminuria and cognitive function in older adults: the Rancho Bernardo study. Am J Epidomiol 2010; 171:277-286.

25 Kurella M, Chertow GM, Fried LF, Cummings SR, Harris T, Simonsick E, Satterfield S, Ayonayon H, Yaffe K: Chronic kidney disease and cognitive impairment in the elderly: the health, aging, and body composition study. J Am Soc Nephrol 2005; 16:2127-2133.

26 Sasaki Y, Marioni R, Kasai M, Ishii H, Yamaguchi S, Meguro K: Chronic kidney disease: a risk factor for dementia onset: a populationbased study. The Osaki-Tajiri Project. J Am Geriatr Soc 2011;59:1175-1181.

27 Seliger SL, Siscovick DS, Stehman-Breen CO, Gillen DL, Fitzpatrick A, Bleyer A, Kuller LH: Moderate renal impairment and risk of dementia among older adults: the Cardiovascular Health Cognition Study. J Am Soc Nephrol 2004;15:1904-1911.

28 Wang F, Zhang L, Liu L, Wang H: Level of kidney function correlates with cognitive decline. Am J Nephrol 2010;32:117-121.

29 Slinin Y, Paudel ML, Ishani A, Taylor BC, Yaffe K, Murray AM, Fink HA, Orwoll ES, Cummings SR, Conneer EB, Jassel S, Ensrud KE: Kidney function and cognitive performance and decline in older men. J Am Geriatr Soc 2008;56:2082-2088.

-30 Seliger ST, Longsstreth WT Jr: Lessons about brain vascular diseases from another pulsating organ, the kidney. Stroke 2008;39:5-6. 